\title{
Physiological Responses of Variable Growth Habit Groundnut (Arachis hypogea L.) Genotypes at Different Planting Densities
}

\author{
M. Swetha Sree ${ }^{1 *}$, P. Sudhakar, V. Uma Mahesh, T. Prathima and T. Giridhara Krishna \\ Department of Crop Physiology, S.V Agricultural College, Tirupati, 517502, \\ Andhra Pradesh, India \\ *Corresponding author
}

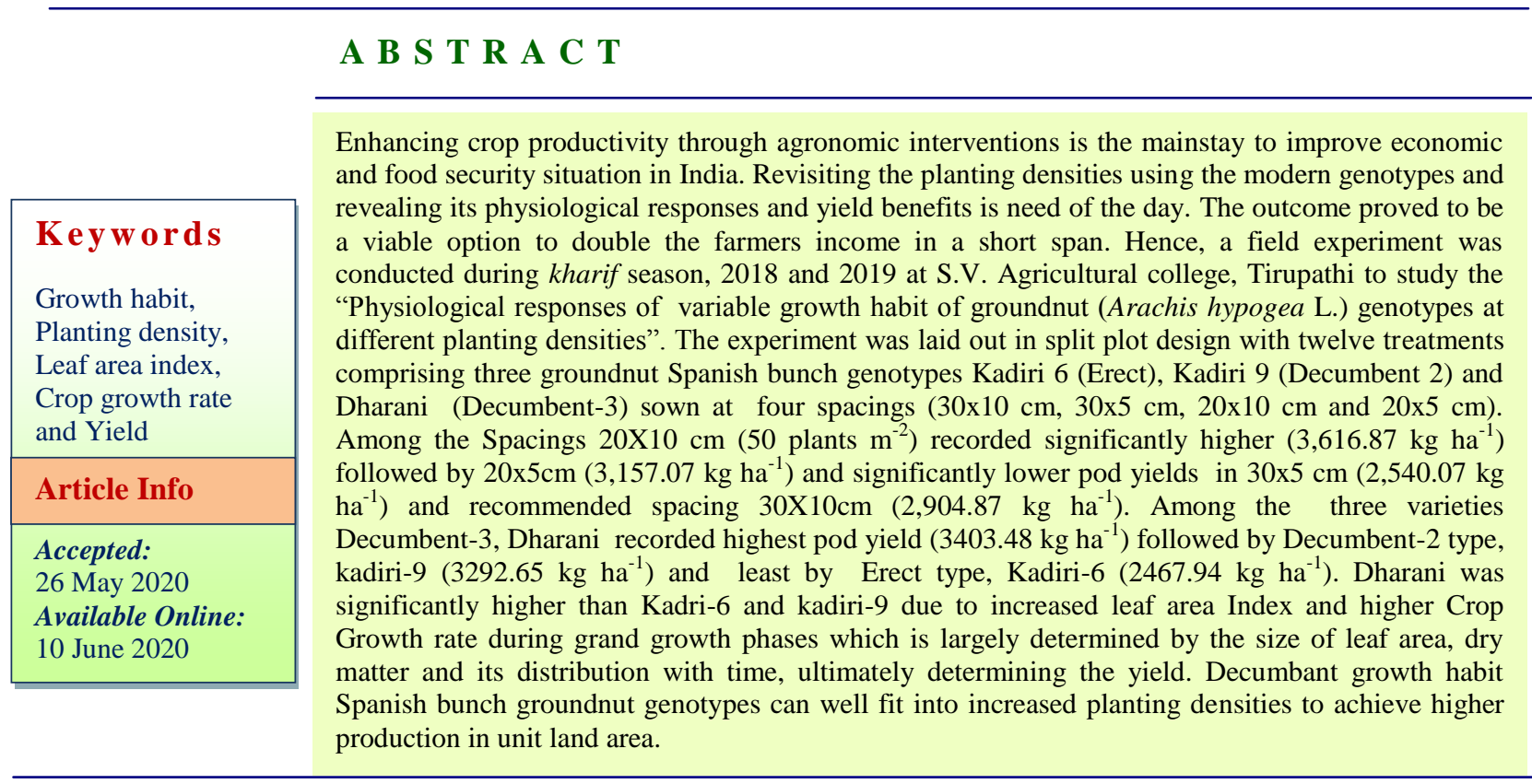

\section{Introduction}

Plants exhibit enormous physiological and functional diversity which underlies variation in growth rates, productivity, population and community dynamics. Groundnut (Arachis hypogaea L.) which is an annual legume, is the 13th most important food crop and 4th most important oilseed crop of the world. Among oilseed crops in India, groundnut accounts for about 50 per cent of area and 45 per cent of oil production. To meet the growing demand, productivity of groundnut has to be improved through genetic improvement, which is obviously a long term goal.

Agronomic interventions are better option to achieve in shorter time span. Revisiting the planting densities per unit area is potential 
option, however growth habit and plant architecture of a genotype plays a critical role. Identifying groundnut genotypes of specific growth habit is a prerequisite to fit into high density planting. Therefore, determining the physiological factors responsible for growth and development of groundnut under increased plant populations in unit area is essential.

Among Ecophysiological traits, Competition results in the preferential accrual of resources by one groundnut plant to its neighbors. Much of the phenotypic variation in plant population reflects in direct effects of environment on plant growth and development i.e., phenoytypic plasticity.

Such studies on physiological responses of groundnut to high density planting were less attempted. An assessment on the impact of high density planting on groundnut would provide basic information required for evaluating suitable varieties of groundnut for densities without losing yield advantages.

Hence an attempt was made to reveal physiological responses of Spanish bunch groundnut genotypes with variable growth habits under increased plant densities.

\section{Materials and Methods}

The present investigation was carried out at dryland farm, S.V. Agricultural College, Tirupati $\left(13.6288^{\circ} \mathrm{N}, 79.4192^{\circ} \mathrm{E}\right)$ during kharif, 2018 and kharif, 2019. The experiment was laid out in split plot design with twelve treatments and three replications.

Three Spanish bunch groundnut genotypes with variable growth habits viz., erect type (Kadiri-6) , decumbent-2 (Kadiri-9) and Decumbent-3 (Dharani) were sown at four plant densities viz., $20 \times 5 \mathrm{~cm}\left(100\right.$ plants $\left.\mathrm{m}^{-2}\right)$, $30 \times 5 \mathrm{~cm}$ (66.6 plants $\left.\mathrm{m}^{-2}\right), 20 X 10 \mathrm{~cm}(50$ plants $\mathrm{m}^{-2}$ ), and recommended spacing of 30 $\mathrm{X} 10 \mathrm{~cm}\left(33.3\right.$ plants $\left.\mathrm{m}^{-2}\right)$. The data on physiological traits like plant height, leaf area, total dry matter, peg to pod ratio, pod yield and harvest index were recorded. Plant height was measured from base of the plant to shoot tip and expressed in centimeters $(\mathrm{cm})$.

The leaf area was recorded using leaf area meter (Li-COR model LI 3000) and expressed as $\mathrm{cm}^{2}$ plant ${ }^{-1}$. Leaf area index was computed taking into account, the area occupied by each plant. The leaf area index was calculated by dividing the total leaf area with the corresponding ground area (Watson.1952).

LAI

$=\underline{\text { Leaf area per plant X Plant population density }}$

land area

Crop Growth Rate (g m ${ }^{-2}$ day $^{-1}$ ) was calculated using the total dry matter of the plant $\mathrm{m}^{-2}$, crop growth rate was calculated as per the formula (Watson, 1952).

$\mathrm{CGR}=\frac{\mathrm{W}_{2}-\mathrm{W}_{1}}{\mathrm{t}_{2}-\mathrm{t}_{1}} \mathrm{X}$

Peg to pod ratio Count the total number of pegs and pods for randomly labeled five plants in each plot. Peg to pod ratio was calculated by using below formula (Bhagavatha et al., 2016).

$$
\text { Peg to pod ratio }=\frac{\text { Number of pods per plant }}{\text { Number of pegs per plant }} \times 100
$$

Harvest Index (\%) was calculated by using the formula (Donald, 1962).

$$
\begin{aligned}
& \text { Economic yield } \\
& \text { Biological yield }
\end{aligned}
$$




\section{Results and Discussion}

\section{Plant height (Cm)}

The plant height of groundnut varieties sown at different spacings was recorded at harvest (Table 1). Pooled data of two seasons revealed that among the three genotypes, Erect type, Kadiri-6 recorded highest plant height $(46.35 \mathrm{~cm})$ followed by Decumbent-3 type Dharani $(44.11 \mathrm{~cm})$ and least by Decumbent-2 type Kadiri-9 $(36.70 \mathrm{~cm})$. Kadiri-6 was significantly higher than Dharani and kadiri-9. Variation in plasticity, growth habit type among genotypes at higher populations resulted in significant variations.

Highest planting density of 100 plants $\mathrm{m}^{-2}$ $(20 \times 5 \mathrm{~cm})$ recorded significantly higher plant height $(52.59 \mathrm{~cm})$ in k-6 and lowest plant height at recommended spacing $(30 \mathrm{X} 10 \mathrm{~cm})$ in k-9 was significantly lower $(30.17 \mathrm{~cm})$.Plant Height is the phenotypic responses for light to reduce deleterious effects of stressful environments. Such complex patterns of plasticity variation may permit diverse genotypes to be maintained in populations inhabiting variable plant densities. Similar results were reported by Ackerely et al., (2000). Interaction effects are non-significant.

\section{Leaf area index (LAI)}

LAI is an important physiological trait specially under variable planting densities because interaction varies between photosynthetically active area and light penetration. The Leaf Area index at $60 \mathrm{DAS}$ is presented (Table 1).

Among the three varieties, Decumbent-3, Dharani recorded highest Leaf Area Index (6.47) followed by Decumbent-2, Kadiri-9 (6.35) and least by Erect type Kadiri-6 (5.05). Dharani was significantly higher than Kadiri9 and kadiri-6. This is due to the different growth habits among the varieties. In the vegetative growth stage, Dharani with wider branch angle had more exuberant development which is beneficial to produce more shoots and leaves and build a wide canopy quickly. This was conducive to intercepting more radiation and growing quickly. Therefore it sustained more LAI and intercepted radiation for longer time resulting with NAR advantage (Carpenter and Board, 1997)

Among the Spacings, 20X5 cm (100 plants $\mathrm{m}^{-2}$ ) recorded significantly higher (8.06) Leaf

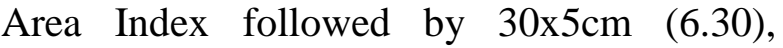
$20 \times 10 \mathrm{~cm}$ (5.37) whereas $30 \times 10 \mathrm{~cm}$ recorded significantly lowest Leaf Area Index (4.12). The trend in total leaf area expansion is a function of total light intercepted. As the plant population increases the total leaf to land area increases resulting higher leaf area index.

Significantly higher leaf Area Index was observed in the interaction of Dharani sown at a spacing of $20 \times 5 \mathrm{~cm}$ (9.53) whereas lowest leaf area index was observed in Kadiri- 6 sown at a spacing of $30 \times 10 \mathrm{~cm}(3.50)$ at harvest stage. Similar reports were reported by Bhagavatha Priya et al., (2016).

\section{Crop growth rate $\left(\mathrm{g} \mathrm{m}^{-2} \mathrm{day}^{-1}\right)$}

The Crop Growth Rate of groundnut genotypes was recorded at 45-60 DAS and presented in the Table 1.

Among the three varieties, Decumbent-2, Kadiri-9 recorded highest Crop Growth Rate $\left(41.95 \mathrm{~g} \mathrm{~m}^{-2}\right.$ day $\left.^{-1}\right)$ followed by Decumbent-3, Dharani (39.24 $\left.\mathrm{g} \mathrm{m}^{-2} \mathrm{day}^{-1}\right)$ and least by Erect type Kadiri-6 (27.94 $\mathrm{g} \mathrm{m}^{-2}$ day $\left.^{-1}\right)$. Kadiri-9 was significantly higher than Dharani and kadiri-6. Among the Spacings, 20X5 cm (100 plants $\mathrm{m}^{-2}$ ) recorded significantly higher $\left(52.53 \mathrm{~g} \mathrm{~m}^{-2} \mathrm{day}^{-1}\right)$ crop growth rate followed by $30 \times 5 \mathrm{~cm}\left(38.89 \mathrm{~g} \mathrm{~m}^{-2}\right.$ day $\left.^{-1}\right), 20 \times 10 \mathrm{~cm}$ 
$\left(30.80 \mathrm{~g} \mathrm{~m}^{-2}\right.$ day $\left.^{-1}\right)$ were as $30 \mathrm{X} 10 \mathrm{~cm}$ recorded significantly lowest crop growth rate $(23.28 \mathrm{~g}$ $\mathrm{m}^{-2}$ day $\left.^{-1}\right)$. More rapid leaf area per unit LAI may contribute to CGR equilibrium across plant populations in soyabean (Carpenter and Board, 1997).

Significantly higher Crop Growth rate was observed in the interaction of Kadiri-9 sown at a spacing of $20 \times 5 \mathrm{~cm}\left(61.07 \mathrm{~g} \mathrm{~m}^{-2}\right.$ day $\left.^{-1}\right)$ whereas lowest Crop growth rate was observed in Kadiri-6 sown at a spacing of 30 $\mathrm{X} 10 \mathrm{~cm}\left(18.41 \mathrm{~g} \mathrm{~m}^{-2} \mathrm{day}^{-1}\right)$ at 45-60 DAS.

\section{Peg to pod}

Peg to pod ratio denotes the reproductive efficiency among the groundnut genotypes. Among the three varieties, Decumbent-3, Dharani recorded highest peg to pod ratio (61.76) followed by Decumbent-2 type, kadiri-9 (54.49) and least by Erect type, kadiri-6 (48.42). Dharani was significantly higher than Kadri-6 and kadiri-9. Dharani which is decumbent -3 with wider branch angle the number of aerial pegs were low in number compared to kadiri-9 and kadiri-6 (Table 2). Aerial peg number increased as results of higher population due to increased plant height and hence, pegs fail to penetrate into the soil.

Peg to pod ratio was maximum at recommended spacing $30 \times 10 \mathrm{~cm}$ (33.3 plants $\mathrm{m}^{-2}$ ). Significant variability in peg to pod ratio was observed among the all spacings. 30X10 $\mathrm{cm}$ (33.3 plants $\mathrm{m} 2$ ) recorded significantly higher peg to pod ratio (65.34) than by $20 \times 10$ $\mathrm{cm}(56.10)$ and significantly higher than 30x5 $\mathrm{cm}$ (53.06) and lowest harvest index was observed in $20 \times 5 \mathrm{~cm}$ (45.07).

These results revealed that peg to pod ratio is affected under increased planting densities. The flowering-pegging and pod filling stages seemed to be very sensitive and yield loss could be prevented by minimizing shade during these stages (Rao and Mittra, 1988).

The data on interaction between varieties and spacings revealed higher peg to pod was observed in the interaction of kadiri-9 sown at a spacing of $30 \times 10 \mathrm{~cm}$ (66.94) whereas lowest peg to pod was observed in kadiri-6 sown at a spacing of $20 \times 5 \mathrm{~cm} \mathrm{(36.95).}$ Similar results were reported by Giayetto et al., (2013)

\section{Pod yield (kg ha $\left.{ }^{-1}\right)$}

Decumbent growth habit genotypes Dharani (Decumbent-3), Kadiri-9 (Decumbent-2) recorded higher pod yields of $3403.48 \mathrm{~kg} \mathrm{ha}^{-1}$ and $3292.65 \mathrm{~kg} \mathrm{ha}^{-1}$ respectively compared to Erect type, Kadiri-6 (2467.94 kg ha-1). Dharani, decumbent-3 growth habit had more yield because of high LAI, CGR and peg to pod number. Similar results were reported by Haro et al., (2013) and Sreelatha et al., (2019).

Among the Spacings, Pod Yield was maximum at $20 \times 10 \mathrm{~cm}$ (50 plants $\mathrm{m}^{-2}$ ). Significant variability in pod yield was observed among the all spacings. $20 \times 10 \mathrm{~cm}$ $\left(50\right.$ plants $\left.\mathrm{m}^{2}\right)$ recorded significantly higher $\left(3,616.87 \mathrm{~kg} \mathrm{ha}^{-1}\right)$ followed by $20 \times 5 \mathrm{~cm}$ $\left(3,157.07 \mathrm{~kg} \mathrm{ha}^{-1}\right), 30 \times 5 \mathrm{~cm}\left(2,540.07 \mathrm{~kg} \mathrm{ha}^{-1}\right)$ were as $30 \times 10 \mathrm{~cm}$ recorded significantly lowest pod yield $\left(2,904.87 \mathrm{~kg} \mathrm{ha}^{-1}\right)$.

Goundnut optimum planting rate reduces intra plant competition during juvenility, enhances plant growth, ground cover and light interception and leads to high dry matter and yield (Zhao et al., 2017).

This might be attributed to more resources at the optimum plant density initiated more leaf area, Leaf area Index, crop growth rate and peg to pod ratio. The data on interaction between varieties and spacings revealed 
significantly higher pod yield when Dharani was sown at a spacing of $20 \mathrm{X} 10 \mathrm{~cm}(4,090.01$ $\mathrm{kg} \mathrm{ha}{ }^{-1}$ ) whereas lowest pod yield was observed in kadiri-6 sown at a spacing of 30 $\mathrm{X} 5 \mathrm{~cm}\left(2,109.59 \mathrm{~kg} \mathrm{ha}^{-1}\right)$. These findings are in conformity with the results of Gabisa et al., (2017)

These variable yields of groundnut genotypes at variable plant populations can be attributed variable LAI and is activity in terms of light interception, photosynthesis, drymatter accumulation. Yield advantage in Dharani, which has decumbent-3 growth habit has wide branch angle and has lower light distribution to the inner canopy.

This resulted from exuberant vegetative organs. Overlong branches and superfluous leaves led to a dense canopy, especially in the upper positions. The closed upper canopy prevented radiation from being transmitted into the lower layers, which contributed to most of the absorption of radiation being focused at the top of the canopy, which indicated that the rapid attenuation of light mainly occurred in the upper canopy had larger and fairly flat leaves, compared with Kadiri-6 which had more erect leaves.

That resulted in a high light loss ratio because more radiation was transmitted through or across the canopy instead of being absorbed by the leaves. Meanwhile, Kadiri-9, which is decumbent-2 the light penetration within the canopy was more gradual and homogeneous, benefiting from the moderate branch length and foliage size.

\section{Harvest index (\%)}

Harvest index denotes the partitioning efficiency of any genotype. Groundnut being semi determinate growth habit, $\mathrm{HI}$ is generally low due to overlapping of vegetative and reproductive growth stages. Among the three varieties, Decumbent-3, Dharani recorded highest harvest Index (37.79 \%) followed by Decumbent-2 type, kadiri-9 (32.49 \%) and least by Erect type, kadiri-6 (25.62 \%). Dharani was significantly higher than Kadri-6 and kadiri-9.

Among the Spacings, harvest Index was maximum at $20 \times 10 \mathrm{~cm}$ (50 plants $\left.\mathrm{m}^{-2}\right)$. Significant variability in harvest index was observed among the all spacings. $20 \times 10 \mathrm{~cm}$ (50 plants $\mathrm{m}^{-2}$ ) recorded numerically higher harvest index $(40.55 \%)$ than by $30 \times 10 \mathrm{~cm}$ (38.75\%) and significantly higher than $30 \times 5$ $\mathrm{cm}(25.98 \%)$ and lowest harvest index was observed in $20 \mathrm{X} 5 \mathrm{~cm}$ (22.59\%). Harvest index in both the genotypes increased with increase in spacing per hectare (Howlader et al., 2009).

The data on interaction between varieties and spacings revealed significantly higher harvest index was observed in the interaction of Dharani sown at a spacing of $20 \times 10 \mathrm{~cm}$ $(48.23 \%)$ whereas lowest harvest index was observed in kadiri-6 sown at 20x5cm (18.06). Similar results were reported by Bhagavatha Priya et al., (2016) and Sreelatha et al., (2019)

The decrease in plant density favours huge vegetative growth and results in lower percent of productive pegs, pods, seed per pod and finally harvest index.

This could be attributed to the rapid development of seed yield in high plant density by optimizing growth factors, once the reproductive phase started, the process of maturation proceeds quickly and leads to harvestable crop while other weather conditions are good. 
Table.1 Physiological traits of variable growth habit groundnut genotypes at different planting densities

\begin{tabular}{|c|c|c|c|c|c|c|c|c|c|}
\hline & \multicolumn{3}{|c|}{ Plant Height $(\mathbf{C m})$} & \multicolumn{3}{|c|}{ Leaf Area Index (LAI) } & \multicolumn{3}{|c|}{ Crop Growth Rate (CGR) } \\
\hline & 2018 & 2019 & POOLED & 2018 & 2019 & POOLED & 2018 & 2019 & POOLED \\
\hline \multicolumn{10}{|l|}{ Varieties (V) } \\
\hline $\begin{array}{l}\text { V1:k6 } \\
\text { (Erect) }\end{array}$ & 44.19 & 48.51 & 46.35 & 5.10 & 5.00 & 5.05 & 37.46 & 18.42 & 27.94 \\
\hline $\begin{array}{l}\text { V2:k9 } \\
\text { (Decumbent-2) }\end{array}$ & 36.03 & 37.36 & 36.70 & 6.29 & 6.41 & 6.35 & 45.26 & 38.64 & 41.95 \\
\hline V3: Dharani (Decumbent-3) & 43.12 & 45.10 & 44.11 & 6.62 & 6.33 & 6.47 & 45.66 & 32.82 & 39.24 \\
\hline Mean & 41.11 & 43.66 & 42.39 & 6.00 & 5.91 & 5.96 & 42.79 & 29.96 & 36.38 \\
\hline SE (m) & 0.65 & 0.52 & 0.37 & 0.04 & 0.07 & 0.04 & 0.74 & 1.80 & 0.59 \\
\hline C.D $(\mathbf{P}=\mathbf{0 . 0 5})$ & 1.95 & 1.58 & 1.33 & 0.12 & 0.21 & 0.12 & 2.25 & 3.93 & 1.77 \\
\hline \multicolumn{10}{|l|}{ Spacing (S) } \\
\hline $\begin{array}{l}\text { S1: } 30 X 10 \mathrm{~cm}(33.3 \\
\text { plants } / \mathrm{m} 2)\end{array}$ & 36.511 & 36.84 & 36.68 & 4.17 & 4.06 & 4.12 & 23.89 & 22.68 & 23.28 \\
\hline $\begin{array}{l}\text { S2: } 30 \times 5 \mathrm{~cm}(66.6 \text { plants } \\
/ \mathrm{m} 2)\end{array}$ & 41.440 & 45.81 & 43.63 & 6.37 & 6.22 & 6.30 & 46.22 & 31.56 & 38.89 \\
\hline $\begin{array}{l}\text { S3: 20x10 cm (50 plants } \\
\text { /m2) }\end{array}$ & 39.978 & 43.25 & 41.62 & 5.34 & 5.39 & 5.37 & 34.33 & 27.28 & 30.80 \\
\hline S4:20x5 cm (100 plants/m2) & 46.536 & 48.72 & 47.63 & 8.14 & 7.97 & 8.06 & 66.74 & 38.31 & 52.53 \\
\hline Mean & 41.12 & 43.66 & 42.39 & 6.01 & 5.91 & 5.96 & 42.80 & 29.96 & 36.38 \\
\hline $\mathbf{S E}(\mathbf{m})$ & 0.44 & 0.67 & 0.34 & 0.04 & 0.08 & 0.04 & 1.27 & 1.85 & 1.22 \\
\hline C.D $(\mathbf{P}=0.05)$ & 1.54 & 2.36 & 1.21 & 0.13 & 0.26 & 0.15 & 4.47 & 6.53 & 4.32 \\
\hline \multicolumn{10}{|l|}{ Interaction(VXS) } \\
\hline V1S1 & 38.43 & 40.66 & 39.55 & 3.59 & 3.41 & 3.50 & 20.53 & 16.29 & 18.41 \\
\hline V1S2 & 45.47 & 50.74 & 48.11 & 5.60 & 5.51 & 5.56 & 39.63 & 19.15 & 29.39 \\
\hline V1S3 & 42.13 & 48.18 & 45.16 & 4.86 & 4.94 & 4.90 & 30.43 & 16.71 & 23.57 \\
\hline V1S4 & 50.73 & 54.45 & 52.59 & 6.35 & 6.12 & 6.23 & 59.27 & 21.53 & 40.40 \\
\hline V2S1 & 31.18 & 29.16 & 30.17 & 4.63 & 4.82 & 4.73 & 26.47 & 28.67 & 27.57 \\
\hline V2S2 & 36.26 & 40.49 & 38.38 & 6.73 & 6.55 & 6.64 & 48.99 & 37.77 & 43.38 \\
\hline V2S3 & 34.57 & 35.94 & 35.25 & 5.37 & 5.90 & 5.63 & 35.57 & 35.99 & 35.78 \\
\hline V2S4 & 42.14 & 43.84 & 43.00 & 8.44 & 8.37 & 8.41 & 70.02 & 52.11 & 61.07 \\
\hline V3S1 & 39.92 & 40.70 & 40.31 & 4.29 & 3.95 & 4.12 & 24.70 & 23.08 & 23.89 \\
\hline V3S2 & 42.59 & 46.20 & 44.39 & 6.77 & 6.61 & 6.69 & 50.03 & 37.77 & 43.90 \\
\hline V3S3 & 43.23 & 45.62 & 44.43 & 5.78 & 5.32 & 5.55 & 36.98 & 29.15 & 33.06 \\
\hline V3S4 & 46.73 & 47.88 & 47.31 & 9.65 & 9.42 & 9.53 & 70.94 & 41.29 & 56.11 \\
\hline MEAN & 41.12 & 43.66 & 42.39 & 6.01 & 5.91 & 5.96 & 42.80 & 29.96 & 36.38 \\
\hline \multicolumn{10}{|l|}{ VXS } \\
\hline $\mathbf{S E}(\mathbf{m})$ & 0.76 & 1.16 & 0.59 & 0.06 & 0.13 & 0.07 & 2.19 & 3.21 & 2.12 \\
\hline $\operatorname{CD}(0.05)$ & NS & 3.37 & 2.35 & 0.26 & 0.45 & 0.25 & NS & 8.42 & 3.92 \\
\hline \multicolumn{10}{|l|}{ SXV } \\
\hline SE(m) & 1.14 & 1.09 & 0.70 & 0.08 & 0.14 & 0.08 & 1.79 & 2.82 & 1.55 \\
\hline CD (0.05) & NS & 3.49 & 2.20 & 0.24 & 0.44 & 0.24 & NS & 9.13 & 5.58 \\
\hline
\end{tabular}


Table.2 Yield and Yield attributes of variable growth habit groundnut genotypes at different planting densities

\begin{tabular}{|c|c|c|c|c|c|c|c|c|c|}
\hline & \multicolumn{3}{|c|}{ Peg to pod ratio } & \multicolumn{3}{|c|}{ Pod yield $\left(\mathrm{Kg} \mathrm{ha}^{-1}\right)$} & \multicolumn{3}{|c|}{ Harvest index (\%) } \\
\hline & 2018 & 2019 & POOLED & 2018 & 2019 & POOLED & 2018 & 2019 & POOLED \\
\hline \multicolumn{10}{|l|}{ Varieties (V) } \\
\hline $\begin{array}{l}\text { V1:k6 } \\
\text { (Erect) }\end{array}$ & 47.81 & 49.04 & 48.42 & 2669.02 & 2266.86 & 2467.94 & 25.87 & 25.37 & 25.62 \\
\hline $\begin{array}{l}\text { V2:k9 } \\
\text { (Decumbent-2) }\end{array}$ & 53.23 & 55.75 & 54.49 & 3714.61 & 2870.69 & 3292.65 & 32.93 & 32.05 & 32.49 \\
\hline $\begin{array}{l}\text { V3: Dharani } \\
\text { (Decumbent-3) }\end{array}$ & 57.25 & 66.17 & 61.71 & 3699.38 & 3107.56 & 3403.48 & 38.03 & 37.54 & 37.79 \\
\hline Mean & 52.76 & 56.99 & 54.87 & 3361.00 & 2748.37 & 3054.72 & 32.28 & 31.65 & 31.97 \\
\hline SE (m) & 1.32 & 1.43 & 1.10 & 114.39 & 42.28 & 62.12 & 1.03 & 0.67 & 0.52 \\
\hline C.D $(\mathbf{P}=0.05)$ & 4.04 & 4.34 & 3.34 & 345.88 & 127.84 & 187.83 & 3.11 & 2.04 & 1.52 \\
\hline \multicolumn{10}{|l|}{ Spacing (S) } \\
\hline $\begin{array}{l}\text { S1: } 30 X 10 \mathrm{~cm} \\
(33.3 \text { plants } / \mathrm{m} 2)\end{array}$ & 65.16 & 65.51 & 65.34 & $3,095.32$ & $2,714.42$ & $2,904.87$ & 39.23 & 38.26 & 38.75 \\
\hline $\begin{array}{l}\text { S2: } 30 X 5 \mathrm{~cm} \\
(66.6 \text { plants } / \mathrm{m} 2)\end{array}$ & 50.42 & 55.71 & 53.06 & $2,758.70$ & $2,321.44$ & $2,540.07$ & 26.64 & 25.33 & 25.98 \\
\hline $\begin{array}{l}\text { S3: } 20 x 10 \mathrm{~cm} \\
(50 \text { plants } / \mathrm{m} 2)\end{array}$ & 54.18 & 58.01 & 56.10 & $3,882.45$ & $3,351.28$ & $3,616.87$ & 41.08 & 40.02 & 40.55 \\
\hline $\begin{array}{l}\text { S4:20x5 cm } \\
\text { (100 plants/m2) }\end{array}$ & 41.42 & 48.72 & 45.07 & $3,707.79$ & $2,606.35$ & $3,157.07$ & 22.16 & 23.01 & 22.59 \\
\hline Mean & 52.80 & 56.99 & 54.89 & $3,361.07$ & $2,748.37$ & $3,054.72$ & 32.28 & 31.66 & 31.97 \\
\hline SE(m) & 1.7 & 1.74 & 0.99 & 143.39 & 36.49 & 77.94 & 1.21 & 0.56 & 0.68 \\
\hline C.D $(\mathbf{P}=0.05)$ & 4.12 & 6.17 & 3.05 & 345.89 & 128.74 & 274.98 & 4.28 & 2.01 & 2.31 \\
\hline \multicolumn{10}{|c|}{ Interaction(VXS) } \\
\hline V1S1 & 56.67 & 58.94 & 57.81 & $2,233.11$ & $2,060.04$ & $2,146.57$ & 32.30 & 32.58 & 32.44 \\
\hline V1S2 & 48.41 & 46.99 & 47.69 & $2,380.84$ & $1,838.17$ & $2,109.51$ & 21.59 & 20.36 & 20.98 \\
\hline V1S3 & 51.53 & 50.93 & 51.23 & $3,220.15$ & $3,100.55$ & $3,160.35$ & 31.67 & 30.36 & 31.01 \\
\hline V1S4 & 34.61 & 39.30 & 36.95 & $2,842.70$ & $2,068.69$ & $2,455.69$ & 17.93 & 18.19 & 18.06 \\
\hline V2S1 & 66.81 & 67.08 & 66.94 & $3,691.70$ & $3,170.21$ & $3,430.96$ & 41.58 & 40.09 & 40.83 \\
\hline V2S2 & 50.45 & 56.16 & 53.31 & $3,136.38$ & $2,355.86$ & $2,746.12$ & 26.47 & 24.94 & 25.71 \\
\hline V2S3 & 55.28 & 56.02 & 55.65 & $4,041.18$ & $3,159.31$ & $3,600.24$ & 42.05 & 41.05 & 41.55 \\
\hline V2S4 & 40.40 & 43.75 & 42.07 & $3,989.17$ & $2,797.41$ & 3,393.29 & 21.61 & 22.11 & 21.86 \\
\hline V3S1 & 72.00 & 70.52 & 71.26 & $3,361.16$ & $2,913.00$ & $3,137.08$ & 43.80 & 42.12 & 42.96 \\
\hline V3S2 & 52.41 & 63.97 & 58.19 & $2,758.88$ & $2,770.31$ & $2,764.59$ & 31.85 & 30.68 & 31.27 \\
\hline V3S3 & 55.75 & 67.09 & 61.42 & $4,386.03$ & $3,793.99$ & $4,090.01$ & 49.51 & 48.64 & 48.23 \\
\hline V3S4 & 49.27 & 63.09 & 56.18 & $4,291.53$ & $2,952.95$ & $3,622.24$ & 26.95 & 28.72 & 27.84 \\
\hline MEAN & 52.80 & 56.99 & 54.89 & $3,361.07$ & $2,748.37$ & $3,054.72$ & 32.28 & 31.65 & 31.97 \\
\hline \multicolumn{10}{|l|}{ VXS } \\
\hline SE(m) & 2.03 & 3.03 & 1.72 & 248.26 & 63.21 & 135.10 & 2.10 & 0.99 & 1.18 \\
\hline $\mathrm{CD}(0.05)$ & NS & NS & NS & NS & 264.98 & 398.90 & NS & 4.23 & 3.24 \\
\hline \multicolumn{10}{|l|}{ SXV } \\
\hline SE(m) & 2.04 & 2.92 & 2.06 & 235.45 & 78.09 & 127.93 & 2.07 & 1.34 & 1.07 \\
\hline CD (0.05) & NS & NS & NS & NS & 244.72 & 410.76 & NS & 3.88 & 3.44 \\
\hline
\end{tabular}


Plant type and canopy structure significantly influence light distribution and interception in the canopy especially under increased plant densities, ultimately effecting crop yield.

Decumbent-3 type growth habit genotype Dharani sown at $20 \times 10 \mathrm{~cm}$ (50 plants $\mathrm{m}^{-2}$ ) resulted in significantly high pod yield $\left(4,090.01 \mathrm{~kg} \mathrm{ha}^{-1}\right)$ whereas lowest pod yield was observed in kadiri-6 sown at $30 \times 5 \mathrm{~cm}\left(2,109.59 \mathrm{~kg} \mathrm{ha}^{-1}\right)$ and at recommended spacing of $30 \times 10$ $\mathrm{cm}\left(2,146.57 \mathrm{Kg} \mathrm{ha}^{-1}\right)$

The study concludes that decumbent growth habit Spanish bunch groundnut genotypes can well fit into high density plantings to reap higher productivity

\section{References}

Ackerly, D.D., Dudley, S.A., Sultan, S.E., Schmitt, J., Coleman, J.S., Linder, C.R., Sandquist, R.D and Geber, M.A. 2000. The Evolution of plant ecophysiological traits: Recent Advances and future directions: New research in addresses natural selection, genetic constraints and the adaptive evolution of plant ecophysiological traits. BioSciences. 50(11): 979-995.

Bhagavatha Priya, T., Subramanyam, D and Sumathi, V. 2016. Performance of groundnut (Arachis hypogaea L.) cultivars under different plant populations during early kharif. Indian Journal of Agricultural Research. 50 (4): 362-365.

Carpenter, A.C. and Board, J.E. (1997). Growth dynamic factors controlling soybean yield stability across plant populations. Crop Science. 37: 15201526.

Donald, C.M. 1962. In search of yield. Journal of Australian institute and Agricultural Science. 8: 111-118.

Gabisa, M., Tana, T and Urage, E. 2017. Effect of planting density on yield components and yield of Groundnut (Arachis hypogeal L.) varieties at Abeya, Borena zone Southern Ehiopia. International Journal of Scientific Engineering and Applied Science. 3(3):748-754.

Giayetto, O., Morla, F.D., Fernandez, E.M., Cerioni, G.A., Kearney, M., Rosso, M.B and Violanate, M.G. 2013. Temporal analysis of branches pod production in peanut genotypes with different growth habits and branching patterns. Peanut Science. 40: 8-14.

Haro, R.J., Baldessari, J., Otegui, M.E. 2013. Genetic improvement of peanut in Argentina between 1948 and 2004: Seed yield and its components. Field Crops Research. 149 (2013) 76-83

Howlader, S.H., Bhashar, H.M., Islam, M.S., Mamun, M.H and Jahan, S.M.H. 2009. Effect of plant spacing on yield and yield attributes of groundnut. International Journal of Crop Production. 4(1): 41-44.

Rao, L. J and Mittra, B.N.1988. Growth and Yield of Peanut as Influenced by Degree and Duration of Shading. Journal of Agronomy and Crop Science. 160: 260265.

Sreelatha, P., Sudhakar, P., Umamhesh, V, Subramanyam, D and Vasanthi, R.P. 2019. Variability in growth and yield attributes among different growth habits of Groundnut genotypes. Indian Journal of Current Microbiology and Applied Sciences. 8(6): 1066-1071.

Watson, D.J., Thron, G.W and French, S.A.W. 1952. Physiological cause of different grain yield between varieties in barley. Annals of Botany. 22: 321-352

Zhao, C., Shao, C., Yang, Z., Wang, Y., Zhang, $X$ and Wang, M. 2017. Effects of planting density on pod development and yield of peanuts under the pattern of precision planted peanuts. Legume Research. 40(5): 901-905 


\section{How to cite this article:}

Swetha Sree, M., P. Sudhakar, V. Uma Mahesh, T. Prathima and Giridhara Krishna, T. 2020. Physiological Responses of Variable Growth Habit Groundnut (Arachis hypogea L.) Genotypes at Different Planting Densities. Int.J.Curr.Microbiol.App.Sci. 9(06): 3717-3725. doi: https://doi.org/10.20546/ijcmas.2020.906.439 